\title{
Does Governance Matter In Infrastructure: Evidence From Sub-Saharan Africa
}

\author{
Olusegun Ayodele Akanbi, University of South Africa, South Africa
}

\begin{abstract}
This study empirically examines the pattern of physical infrastructure that would unlock the productive potential of sub-Saharan Africa. The estimations were carried out in a panel of 21 selected sub-Saharan African countries over the period 2000 to 2010 using the two-stage least squares (TSLS) estimation techniques. The infrastructure variable was constructed on the basis of three physical infrastructure stocks (roads, telecommunication and electricity) using the principal component analysis (PCA), and governance was measured using the worldwide governance indicators. The results conform to the findings of existing literature; namely, that real output, government capital expenditure, external balance and inflation are significant determinants of physical infrastructure in sub-Saharan Africa. The distinctive feature of the study is the significant role played by governance in explaining physical infrastructure. The results from the panel estimations reveal that investment in governance/institutional structures is a necessary first step in providing quality infrastructure stock and, hence, pro-poor, long-term economic growth for the region. Therefore, in modelling physical infrastructure, it is imperative to incorporate the important role played by governance. ${ }^{\text {I }}$
\end{abstract}

Keywords: Infrastructure; Governance; Economic Growth; Sub-Saharan Africa

\section{INTRODUCTION}

C

nfrastructural development, in effect, sets the foundation for broad-based sustainable long-term economic growth and development. Quality infrastructure facilities create conducive socioeconomic environment in which private sector initiatives can be boosted. Therefore, in the process of eradicating global poverty, an efficient stock of physical infrastructure is required and should be one of the core objectives of government in developing and low-income countries. The improvement in infrastructure will not only boost growth in the economy, but will also increase the level of productivity, which is an important ingredient in economic development.

Supporting infrastructure investment in Africa, as outlined in Kandiero (2009), is one of the most crucial catalysts for achieving the developmental goals; but infrastructure deficits have been the major constraint on growth in many African economies. Although the continent has been projected to be one of the fastest-growing continents in the world, with over 5\% average growth per annum over the medium term, this could be even higher if the backlog of infrastructure deficits were removed. Currently, about $40 \%$ of the sub-Saharan African population lacks access to safe water, $60 \%$ lacks basic sanitation, $30 \%$ of the rural population has access to all-season roads and $30 \%$ of the total population has access to electricity (Kandiero, 2009).

Given the strong evidence - both in the literature and in real life - of the enormous role that infrastructure plays in achieving pro-poor, long-term economic growth, it is imperative to delve into the factors that drive infrastructure. The literature has identified major macroeconomic variables as being responsible for the level of infrastructure development (Bourque, 1985, and Hammami, Ruhashyankiko, and Yehoue, 2006). Macroeconomic stability, level of economic activity, government capital expenditure and resource endowment are among the major

\footnotetext{
${ }^{1}$ The first draft of this paper has been published in the conference proceedings of the $2^{\text {nd }}$ Annual International Conference on Micro and Macro Economics, 2012. Please note that Substantial modifications have been made to the paper.
} 
macro determinants of infrastructure previously investigated. However, the role of governance/institutions in influencing physical infrastructure has not been thoroughly investigated in the literature. According to Rodrik, Subramanian and Trebbi (2004), the quality of institutions - as a determinant - overrides any other factors that drive the economy. These authors found that the quality of institutions has a more positive and significant effect on economic performance than geography and trade integration.

This study, however, augments the existing literature on the determinants of infrastructure in the context of the sub-Saharan African countries and investigates the important role of governance in explaining physical infrastructure in sub-Saharan Africa. An infrastructure variable was constructed, based on the three infrastructure stocks of (i) roads, (ii) telecommunication and (iii) electricity, which distinguishes it from the single-infrastructure stock commonly used in the literature. On the other hand, the concept of governance used in this study comprises the traditions and institutions by which authority in a country is exercised. This includes the process by which those in authority are selected, monitored and replaced; the capacity of the government to effectively formulate and implement sound policies; and the respect of citizens and the state for the institutions that govern economic and social interactions among them (Kaufmann, Kraay and Zoido-Lobaton, 1999).

Firstly, in line with Kaufmann et al (1999), governance is broadly defined as the process of selecting, monitoring and replacing those in authority and is represented by "voice and accountability", while "political instability and violence" includes a measure of the extent to which citizens of a country are able to participate in choosing their leaders and the likelihood that the government in power will be destabilised or overthrown by possibly unconstitutional or violent means. Secondly, the capacity of the government to effectively formulate and implement sound policies combines the perceptions of the quality of public service provision, the quality of the bureaucracy, the competence and independence of the civil service from political pressures, incidence of marketunfriendly policies (such as price controls or inadequate bank supervision), as well as the burden of excessive regulation in areas such as foreign trade and business development. Lastly, the respect of citizens and the state for the institutions that govern economic and social interactions represents "the rule of law and control of corruption", and includes a measure of the extent to which agents have confidence in and abide by the rules of the society and the exercise of public power for private gains.

Against this background, the results of the estimates are significant and consistent with theoretical expectation, revealing the important role that governance is playing in physical infrastructure development in subSaharan Africa. Hence, the analysis tends to shed light on the direction that policy makers should take to improve the level of governance in the region.

The rest of the study is structured as follows: Section 2 presents a review of the importance of governance in infrastructure, while Section 3 describes the methodology used and the measures of infrastructure and governance. It also provides the description of the data used in the study. Section 4 presents the stylised facts, which also reveal the technical relationship that exists between governance and infrastructure. In Section 5, the empirical analysis and estimation results are presented, and Section 6 concludes the study.

\section{RELEVANCE OF GOVERNANCE IN INFRASTRUCTURE DEVELOPMENT: A REVIEW}

Governance plays a significant role in the development process of any economy and, to an even greater extent, in the development of infrastructure. It is central to major development outcomes and, therefore, weak governance can have an enormously negative impact on returns on infrastructure investment (Kenny, 2007). The link between governance, infrastructure and economic development has continued to gain recognition in the context of global policy making. Over the past three decades, the concept of governance has risen from obscurity to exhortation status (Dixit, 2009). According to EconLit, the word "governance" was mentioned only five times in 1970, whereas by 2008 it was mentioned 33,177 times. This development has brought an awareness to the literature that the established fundamental economic theories cannot work effectively in an economic environment where governance is weak. The concept of governance can be seen from two different angles: economic governance and corporate governance, which are often used interchangeably. Economic governance, as defined by Dixit, is the structure and functioning of the legal and social institutions that support economic activity and transactions by protecting property rights, enforcing contracts and taking collective action to provide physical and organisational 
infrastructure. Dixit regards this kind of governance as the more important of the two, since markets and economic activity cannot function well in its absence.

Good governance remains the pillar of poverty-reduction strategies prescribed by major international development institutions (e.g. the World Bank, IMF, African Development Bank and the United Nations) in recent times. In the process of eliminating poverty, infrastructure development remains a key and, therefore, an appropriate institutional and policy framework (good governance) is needed to achieve the desired objective. A region's infrastructural development largely depends on its institutional strength and diversity. It is the socioeconomic climate created by the institutions that will improve infrastructure and will serve as a medium for more trade and investment (De, 2010). Diversity of political systems and institutional cultures has also been recognised by the Asian Development Bank (ADB) as the strategic priority in eliminating poverty. The ADB defines four aspects of sound governance - accountability, participation, predictability and transparency - which are applicable to all countries (ADB, 2009).

In this milieu, there is an urgent need to invest in improving governance and the institutional environment in order to achieve the desired level of infrastructural development that will lead to sustainable long-term growth and development. Kuroda, Kawai and Nangia (2007: 253) stressed that the strong need for planning and coordination of cross-border infrastructure requires a systematic institutional arrangement.

Emphasis on governance of infrastructure as the catalyst for developing economies to escape poverty has been increasing steadily over the years. The importance of good governance was highlighted in the World Bank's 1994 World Development Report on infrastructure, which tackled a range of issues, including public and private roles in provision and regulation and management of state-owned enterprises. Over the last two decades there has been a considerable change in the delivery of infrastructure, especially in developing countries. There has been a shift from state-owned to private-owned enterprises - where more stable institutions are in place - but this has not totally eradicated the institutional weaknesses underlying poor provision of infrastructure (Kenny, 2007). This indicates that, regardless of ownership, good governance remains the key to infrastructural development.

The societal cost of corruption (an element of governance) in infrastructural provision remains a huge constraint on economic development. Kenny (2007) refers to corruption as a symptom of failed governance, which can act to further weaken the governance environment. According to Kenny, corruption practices not only raise the price of infrastructure, but can also reduce the quality of and economic returns on infrastructure investment. Estimates regarding the cost of corruption in infrastructure suggest that 5-20\% of construction costs are being lost to bribe payments, and as much as $20-30 \%$ of electricity is being stolen by consumers in collusion with staff (Gulati and Rao, 2006). Assuming the 5\% costs, the financial burden would translate to about US\$18 billion a year in developing countries (Kenny, 2009). To reduce corruption and strengthen the governance environment, Kolstad and Wiig (2009) have suggested transparency as the key factor.

Optimal regional infrastructure cannot be achieved without adequate regulation and institution (Organisation for Economic Co-operation and Development (OECD), 2009). Therefore, good governance is essential for achieving a flawless Africa. Despite the multidimensional nature of governance, this study attempts to test the hypothesis of whether good governance translates into improved infrastructure. But before that can be done, we need to consider how governance and infrastructure are measured.

\section{METHODOLOGY AND DATA}

A panel data econometric technique was used in estimating the empirical relationship between governance and infrastructure within 21 cross-sectional data points of selected sub-Saharan African countries over the period 2000-2010. ${ }^{2}$ The two-stage least squares (TSLS) estimation technique was adopted to account for endogeneity of the variables. The model and its specifications are discussed in section 5 of this paper. The data used have been obtained from the World Bank, the African Development Indicators and the Worldwide Governance Indicator database.

\footnotetext{
${ }^{2}$ The list of countries used in this paper is presented in Appendix B. Other sub-Saharan African countries were excluded from the estimation mainly because of non-availability of data for some variables over the entire period.
} 


\subsection{Measuring Governance}

The worldwide governance indicators developed by Kaufmann et al (1999) were utilised in this study as a measure of governance. These represent the components of governance and institutions that are most influential for infrastructure development. The indices cover a broad range of policy and institutional outcomes for a large number of countries and include the rule of law, corruption, government effectiveness, regulatory quality, voice and accountability, and political instability. These indices are also employed in De (2010) as a measure of governance. In order to capture governance in a broader context, the average value of the six elements in the governance indicators is used as a measure of governance. The governance scores range from -2.5 to +2.5 , with -2.5 representing the worst governance and +2.5 the best governance. Most of the governance scores for sub-Saharan African - and developing -countries remain in the negative range.

\subsection{Measuring Infrastructure}

In this study, infrastructure is represented by a composite physical infrastructure index (PII), which is based on three infrastructure stocks of (i) roads, (ii) telecommunication and (iii) electricity. Empirical literature on the link between infrastructure and economic development has been plagued by single-infrastructure stock (Calderon, 2009). The measure of telephone penetration and electricity generation has been used widely in the literature as a proxy for infrastructure (Easterly, 2001, and Loayza, Fajnzylber and Calderón, 2005). This approach may not be able to produce a robust estimated impact of infrastructure on economic growth, given the high degree of correlation that exists among the different measures of infrastructure stocks. To avoid this shortcoming, Calderon and Servin's (2004) approach was adopted in building an aggregate index that combines the three infrastructure stocks. In addition, the aggregation of the infrastructure stocks will help to reduce the measurement error associated with a single-infrastructure indicator.

It is evident that many of the variations in a particular infrastructure stock across countries are explained by differences in countries' geographic and demographic characteristics (Calderon and Servin, 2004). Therefore, the first step in constructing the PII is to take the residuals from the regression of a particular infrastructural stock. ${ }^{3}$ Estimates from the regression are satisfactory and are similar to the findings of Calderon and Servin. Each infrastructural stock is measured as total road network per $1000 \mathrm{~km}$, electricity generation per 1,000 people and number of telephone (mainline $\&$ mobile phone) subscribers per 1,000 people.

The residual series derived from each regression is aggregated using the principal component analysis (PCA). The PCA is a process of taking high-dimension sets of indicators and transforming them into new indices that capture information on a different dimension and are mutually uncorrelated. To derive an aggregated index for infrastructure stocks, the first eigenvectors (loading matrix) from the principal component analysis were used as the required weights, such that the linear combination is as follows:

$$
P I I=a_{1} X_{1}+a_{2} X_{2}+a_{3} X_{3}
$$

where $a_{1}, a_{2}, \& a_{3}$ are the eigenvector (weights) from the PCA and $X_{1}, X_{2}, \& X_{3}$ are the three synthetic infrastructure stocks. ${ }^{4}$ Appendix A shows the eigenvalues and eigenvectors of the PCA.

\footnotetext{
${ }^{3}$ Each infrastructural stock (roads, telecommunication and electricity) is regressed on the labour force, urbanisation ratio and land area.

${ }^{4}$ Smith (2002) suggests the use of the first principal component (largest eigenvalues) as the required weights. In line with Calderon (2009), the PCA is based on the correlation matrix rather than the covariance matrix.
} 


\section{GOVERNANCE AND INFRASTRUCTURE: CROSS-COUNTRY COMPARISON}

The cross-country analysis presented in this section is based on the constructed governance and infrastructure index mentioned in Section 3. Figures $1 \& 2$ present a global ranking of the ten best and worstperforming countries, based on the governance indicator (GI), while Table 1 presents the ranking for the SSA countries. A similar comparison is presented based on the infrastructure index (Tables 2 and 3).

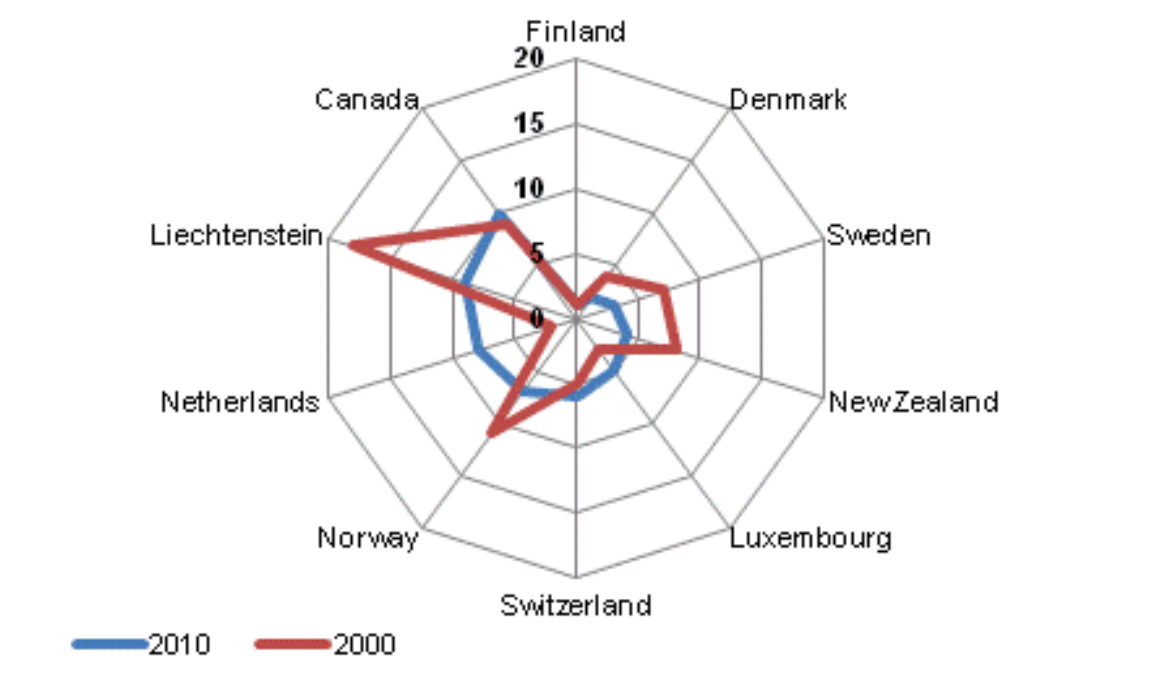

Figure 1: Global Ranks of Top 10 Countries in Governance Index (GI) Source: Worldwide governance indicators and author's own calculations. No. of countries: $2010=210 ; 2000=196$

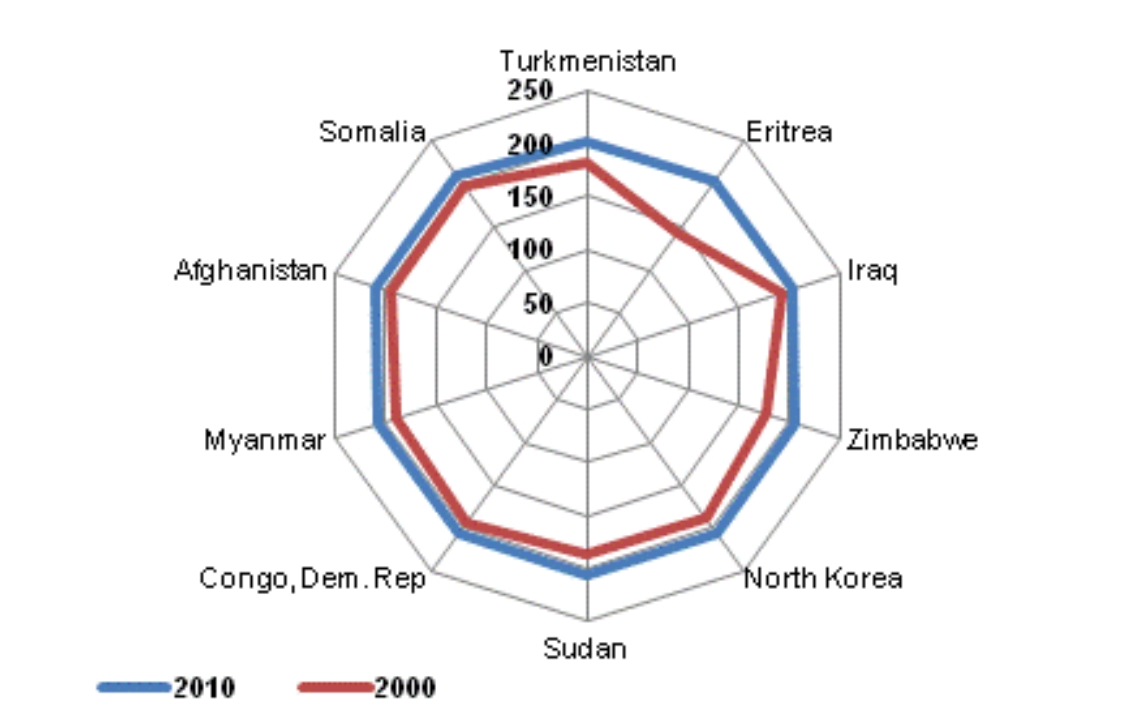

Figure 2: Global Ranks of Lowest 10 Countries in Governance Index (GI) Source: Worldwide governance indicators and author's own calculations. No. of countries: $2010=210 ; 2000=196$

With the exception of New Zealand and Canada, the top ten countries with good governance continued to be led by European countries. This composition has remained the same, except for Norway and Liechtenstein, which were ranked $11^{\text {th }}$ and $18^{\text {th }}$, respectively, in 2000. It is noticeable that there is stiff competition among the topperforming countries to maintain their positions, whereas the ten lowest countries have shown no improvement in governance since 2000; most worrying of all, they are mostly SSA countries. 
There have been mixed performances of the SSA countries in GI over the years. Despite some improvement in rankings and scores, many SSA countries are still operating at a poor level of governance (Table 1). Not much variation exists in governance rankings among SSA countries, as most fall at the lower end of the global ranking. However, a country's improvement in governance ranking may not necessarily translate into improvement in governance scores. For instance, Seychelles's ranking improved between 2000 and 2010, but it has recorded a decline in its governance scores. Similarly, Cameroon has improved in its governance scores, but its ranking has deteriorated.

Table 1: Global Ranks of Sub-Saharan African Countries in Governance Index (GI)

\begin{tabular}{|c|c|c|c|c|c|}
\hline Country & 2010 & 2000 & Country & 2010 & 2000 \\
\hline Mauritius & $54 *(\uparrow)$ & 42 & Niger & 162 & 140 \\
\hline Botswana & 62 & 47 & Sierra Leone & $158 *(\uparrow)$ & 186 \\
\hline Cape Verde & $68(\uparrow)$ & 57 & Kenya & $159 *(\uparrow)$ & 152 \\
\hline Namibia & $75^{*}(\uparrow)$ & 76 & Cameroon & $174 *$ & 159 \\
\hline South Africa & 78 & 63 & Liberia & $166^{*}(\uparrow)$ & 192 \\
\hline Ghana & $89 *(\uparrow)$ & 94 & Togo & 175 & 156 \\
\hline Seychelles & $87(\uparrow)$ & 74 & Angola & $184 *(\uparrow)$ & 191 \\
\hline Lesotho & $105^{*}(\uparrow)$ & 98 & Ethiopia & 179 & 160 \\
\hline Mozambique & $113 *(\uparrow)$ & 115 & Guinea-Bissau & 185 & 166 \\
\hline Benin & 119 & 91 & Congo & $183 *(\uparrow)$ & 182 \\
\hline Tanzania & $125 *(\uparrow)$ & 132 & Comoros & $182 *(\uparrow)$ & 170 \\
\hline Burkina Faso & $117 *(\uparrow)$ & 109 & Burundi & $190 *(\uparrow)$ & 188 \\
\hline Zambia & $127 *(\uparrow)$ & 128 & Nigeria & 191 & 168 \\
\hline Senegal & 134 & 96 & Cote d'Ivoire & 193 & 164 \\
\hline Malawi & $114^{*}(\uparrow)$ & 113 & Equatorial Guinea & $195^{*}(\uparrow)$ & 183 \\
\hline Sao Tome And Principe & 130 & 89 & Central African Republic & 198 & 177 \\
\hline Mali & 135 & 114 & Eritrea & 202 & 144 \\
\hline Rwanda & $111 *(\uparrow)$ & 180 & Guinea & 196 & 176 \\
\hline Gambia & 141 & 117 & Chad & 200 & 161 \\
\hline Swaziland & $140 *(\uparrow)$ & 138 & Sudan & 206 & 187 \\
\hline Madagascar & 164 & 102 & Congo, Dem. Rep. & $207 *(\uparrow)$ & 194 \\
\hline Gabon & 149 & 102 & Zimbabwe & 204 & 178 \\
\hline Uganda & $152 *(\uparrow)$ & 146 & Somalia & 210 & 196 \\
\hline
\end{tabular}

Source: Worldwide governance indicators and author's own calculations.

No. of countries: $2010=210 ; 2000=196$. $(\uparrow)$ means improvement in ranks and $*$ means improvement in scores between 2000 and 2010 .

Empirical evidence has shown that investment in physical infrastructure, such as roads, electricity and telecommunication, requires a sufficiently long-term and significantly large intra-generational resource transfer. Regional infrastructural development, in its strictest form, can be seen as a catalyst for crowding-in private investment, and the absence of these facilities in an economy may result in lower productive efficiency (Munnell, 1990).

Table 2 presents global rankings of the best- and worst-performing countries based on the World Economic Forum (WEF) global infrastructure rankings. These rankings were used to check the relative robustness of the PII, as presented in Table $3 .^{5}$

Interestingly, the $2010 \mathrm{WEF}$ rankings on infrastructure revealed the strong link between physical infrastructure development and economic development, as the developed economies occupied the top 10 positions while the developing and less-developed economies are at the bottom 10 of the 133 countries surveyed. Most SSA countries are at the bottom of the rankings, with Nigeria, Chad Republic and Angola showing a significant deterioration in infrastructure quality.

${ }^{5}$ Owing to lack of available time series on infrastructure index from the WEF, the paper could not estimate infrastructure determinants based on the WEF index. 
Table 2: Global Rankings of Countries in Infrastructure

\begin{tabular}{|l|c|l|c|}
\hline Top 10 Countries & Rank $=\mathbf{2 0 1 0}$ & Bottom 10 Countries & Rank= 2010 \\
\hline Switzerland & 1 & Bangladesh & 130 \\
\hline Hong Kong & 2 & Chad & 131 \\
\hline Singapore & 3 & Lebanon & 132 \\
\hline France & 4 & Nepal & 133 \\
\hline Iceland & 5 & Nigeria & 134 \\
\hline Austria & 6 & Paraguay & 135 \\
\hline Sweden & 7 & Romania & 136 \\
\hline Finland & 8 & Mongolia & 137 \\
\hline Germany & 9 & Angola & 138 \\
\hline Denmark & 10 & Bosnia & 139 \\
\hline Source: & & \\
\hline
\end{tabular}

Source: World Economic Forum

From the selected 21 SSA countries, the infrastructure index rankings, in terms of the PII between 2000 and 2010, revealed a relatively good standing and significant improvement in the Southern African countries compared with other regions on the continent (Table 3). This positive development can also be aligned with the relatively good economic conditions in this region. In comparison, the PII is largely consistent with the WEF rankings, despite the fact that the former measures quantity while the latter measures quality.

Table 3: Rankings of SSA Countries in Infrastructure, Based on the PII and WEF

\begin{tabular}{|c|c|c|c|}
\hline Country & 2010 PII & 2000 PII & 2010 WEF \\
\hline Botswana & 1 & 2 & 3 \\
\hline South Africa & 2 & 5 & 2 \\
\hline Togo & 3 & 8 & N/A \\
\hline Congo & 4 & 10 & N/A \\
\hline Ethiopia & 5 & 15 & 8 \\
\hline Namibia & 6 & 13 & 1 \\
\hline Gabon & 7 & 6 & N/A \\
\hline Cote d'Ivoire & 8 & 3 & 4 \\
\hline Cameroon & 9 & 17 & 12 \\
\hline Kenya & 10 & 19 & 7 \\
\hline Zimbabwe & 11 & 1 & 9 \\
\hline Angola & 12 & 18 & 16 \\
\hline Zambia & 13 & 12 & 10 \\
\hline Ghana & 14 & 7 & 6 \\
\hline Sudan & 15 & 9 & N/A \\
\hline Mozambique & 16 & 14 & 13 \\
\hline Nigeria & 17 & 20 & 15 \\
\hline Benin & 18 & 11 & 11 \\
\hline Tanzania & 19 & 16 & 14 \\
\hline Senegal & 20 & 4 & 5 \\
\hline Congo, Dem. Rep. & 21 & 21 & N/A \\
\hline
\end{tabular}

Source: World Economic Forum (WEF) and author's own calculations.

PII rankings are based on the 21 selected SSA countries and WEF rankings are based on the 25 SSA countries included in the WEF survey (i.e., the first to the last SSA countries' ranks).

The scatter plot of PII and governance suggest a strong positive association between the two variables (Figure 3). This implies that countries with better governance have also enjoyed higher stock of infrastructure. Most elements of governance have partial correlation coefficients in the high range of 0.6 and $0.8{ }^{6}$ Correlation with the average governance index (GI) stood at 0.77 . Therefore, if there is a causal relationship between infrastructure and governance, it must be positive.

${ }^{6} \mathrm{De}(2010)$ estimates among Asian countries, ranging from 0.6 to 0.9 .

C 2013 The Clute Institute http://www.cluteinstitute.com/ 

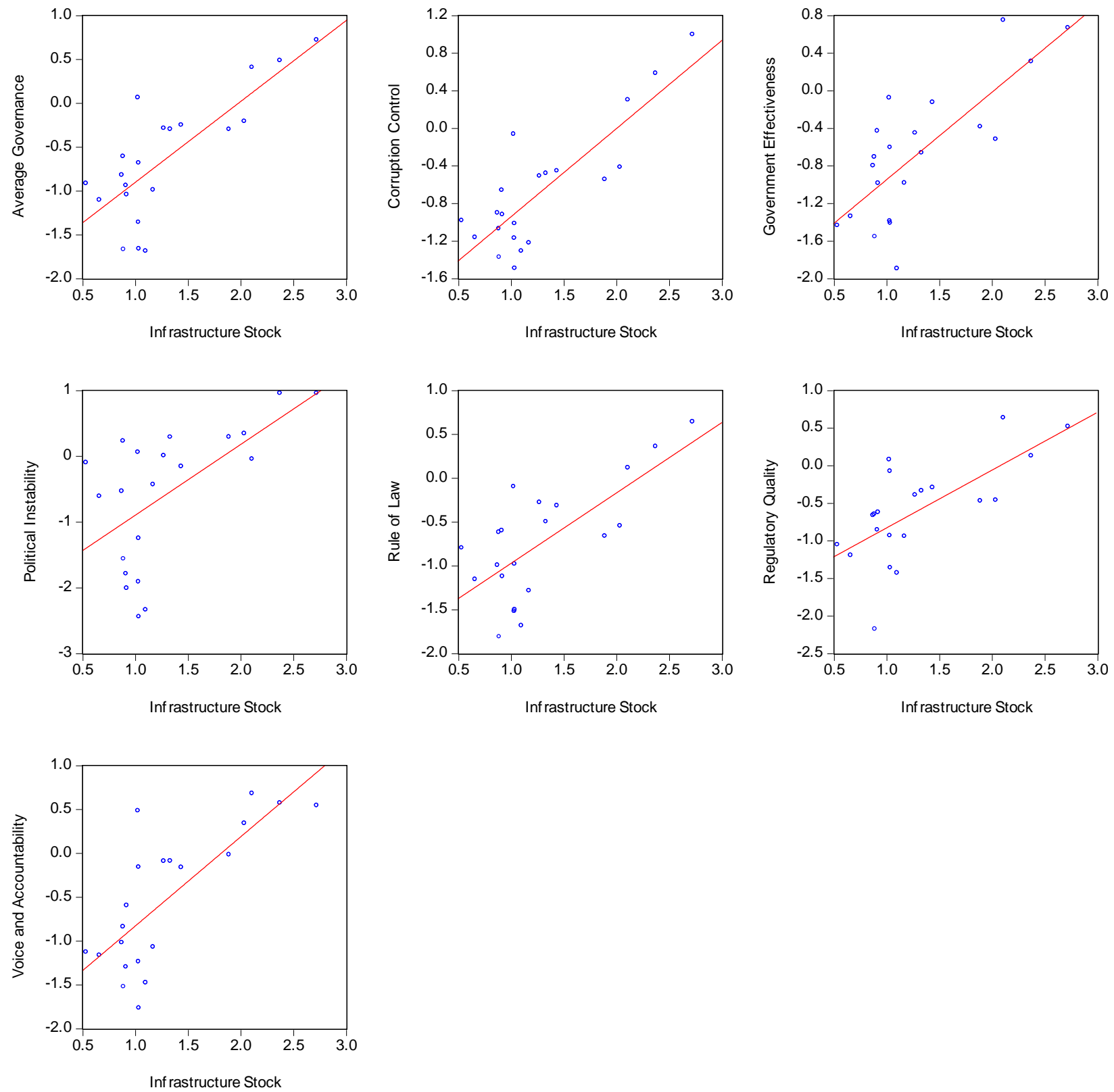

Figure 3: Scatter Plot of Infrastructure and Governance Source: Author's own calculations

Table 4: Pairwise Granger Causality Test for Infrastructure, GDP and Governance

\begin{tabular}{|c|c|c|}
\hline Null hypothesis & F-statistic & P-value \\
\hline Infrastructure does not granger-cause GDP & 1.05469 & 0.37848 \\
\hline GDP does not granger-cause infrastructure & 1.00514 & 0.39483 \\
\hline Governance indicator does not granger-cause infrastructure & 0.55058 & 0.59051 \\
\hline Infrastructure does not granger-cause governance & 4.15535 & 0.04253 \\
\hline
\end{tabular}

Source: Author's own calculations

To test whether the lags of a particular variable enter into the equation for another variable, a Granger causality test is necessary (Enders, 2004). Table 4 presents the Granger causality test for PII, GDP and governance with a lag over the period between 2000 and 2010. From the result, it is impossible to accept the null hypothesis that 
infrastructure and GDP do not influence each other. This again confirms the evidence established in the literature; namely, that there is a dual causal relationship between infrastructure and GDP. Looking at the causality between governance and infrastructure, here, too, it is impossible to accept the null hypothesis that governance does not affect the performances of infrastructure. Therefore, in addition to the positive correlation between governance and infrastructure, it is expected that improved governance will help countries attain higher levels of infrastructure development.

\section{EMPIRICAL ANALYSIS: DETERMINANTS OF INFRASTRUCTURE}

The empirical strategy applied in this study is based on estimation of a simple equation relating infrastructure and governance, while controlling for other exogenous factors in a panel data setting. The estimated equation adopted in this study draws from De (2010) and Bourque (1985).

In this study, physical infrastructure was determined by a country's economic size, government expenditure, international demand, inflation rate and level of governance. Therefore, to test the hypothesised determinants of physical infrastructure, the following equation was modelled:

$$
\ln \_p i i_{i t}=\beta_{1}+\beta_{2} \ln \_g d p_{i t}+\beta_{3} \ln \_g c e_{i t}+\beta_{4} e b_{i t}+\beta_{5} \ln \_i n f_{i t}+\beta_{6} g o v_{i t}+e_{i t}
$$

where

pii $=$ physical infrastructure index

gdp $=$ gross domestic product

gce $=$ government capital expenditure

$\mathrm{eb}=$ external balance

inf $=$ inflation

gov $=$ governance index

and $e_{i t}$ is the error term. The subscript $(i t)$ refers to country and time period respectively. All variables are presented in their natural logarithm forms, except for external balance and governance index, which have negative values.

The specification of the model reveals a possible simultaneity problem among the regressors, which has rendered the use of ordinary least squares (OLS) to be inappropriate in the estimations. In order to derive robust estimates of the parameters in equation 2, a two-stage least squares (TSLS) estimation method was adopted and the lag values of the dependent and independent variables were used as instruments to remove the simultaneity problem that exists among the regressors. In addition, country-specific characteristics were considered in the estimation, assuming that, although these sub-Saharan African countries have similar economic structures, there are still major differences in the stock of regional infrastructure and their structure of governance. Given this fact, the study carried out the TSLS with fixed-effect estimation techniques and added an interactive dummy variable as an instrument to capture the huge physical infrastructure differences that exist between South Africa and other SSA economies.

The gross domestic product - a measure of a country's economic size - is expected to pose a positive relationship with infrastructure, as evidenced in the literature. Therefore, an increase in economic activity will create an opportunity for improvements in physical infrastructure; likewise, an increase in infrastructure will lead to higher economic activity, as shown in Table 4.

In this context, the provision of physical infrastructure can be viewed as a major responsibility of government. Therefore, government budget allocations towards more capital expenditure will go a long way in improving infrastructure capacity in the economy. Bourque (1985) postulates an infrastructure gap, which addresses the central question of why government capital outlays have failed to keep pace with the growing needs of society. Bourque explained that capital outlays have been crowded out by competing demands for public funds, particularly spending for expanding government social service programmes. This has led policy makers to change the expenditure mix in favour of social services, thus crowding out physical infrastructure development. However, it is 
expected that an increasing government capital expenditure will play a significantly positive role in the long-term infrastructure equation.

Macroeconomic stability, as evidenced in the literature, has also played an important role in infrastructure building (Bourque, 1985, and Hammami et al, 2006). An unstable macroeconomic environment will have a distortionary effect on infrastructure development, as the real value of expenditure on infrastructure may decline. More investment in infrastructure is more prevalent in countries with credible, predictable and stable macroeconomic conditions. This is reflected in the level of inflation.

External balance is reflected in trade flows (exports and imports). De (2010) found that trade openness (integration) has a positive impact on infrastructure. He defines openness as the ratio of the sum of exports and imports to GDP. The use of external balance - the difference between exports and imports - is also expected to capture the performance of infrastructure. This means that countries with greater exogenous or external resources (aid or oil) should be in a better position to improve their infrastructure capability. Given that Africa has a huge natural resource endowment and is the recipient of much aid, external balance is better placed to explain infrastructure than trade openness.

The governance measure, as explained earlier, is expected to have a positive impact on the level of physical infrastructure. Therefore, an increased level of governance represents better governance, which will eventually increase infrastructure stock.

Against this background, the results of the estimations are presented in Table 5. In order to see the effects of the various elements of governance used in the study, seven equations were estimated. Each equation controls for the existing macroeconomic variables, but is augmented with governance. In addition, the results are robust, with Rsquare coefficients ranging from 0.72 to 0.87 across the seven equations.

All the macroeconomic variables are found to be statistically and economically significant determinants of infrastructure, except for government capital expenditure in some of the equations, where there is statistical insignificance. The results (equation 1) show that a $1 \%$ increase in GDP will lead to an increase of about $0.2 \%$ in the level of infrastructure. This will lead to an increase of about $0.1 \%$ when government capital expenditure is increased by $1 \%$. The economic significance of the external balance variable may be ambiguous, as the result translates into a US $\$ 1$ billion increase in net resources, which is expected to boost the level of infrastructure by about $0.02 \%$ among the selected sub-Saharan African countries. An improvement in the level of macroeconomic stability (lower inflation) by $1 \%$ will lead to an increase of about $0.2 \%$ in infrastructure.

Looking at the effects of governance on infrastructure development, the overall average governance indicator (equation 1) is found to have a strong impact when all other macroeconomic variables have been controlled for. A unit increase in the average level of governance (better governance) will lead to a rise of about $0.5 \%$ in the stock of regional infrastructure. This again indicates that good quality institutions will overrule all other criteria needed to achieve desired developmental objectives (Rodrik et al, 2004).

Equations 2 to 7 reflect the results of the specific elements of governance considered in the study. The effects of the six elements of governance on infrastructure development are also found to be significant, except for the rule of law (equation 7), which does not conform (negative sign) to theoretical expectation. This could be attributed to its weaker linkage to physical infrastructure stock than all other elements of governance. In other words, the respect of citizens and the state for the institutions that govern economic and social interactions (rule of law) will have a more indirect impact on infrastructure stock, rather than a direct impact. 
Table 5: Estimation Results

\begin{tabular}{|c|c|c|c|c|c|c|c|}
\hline & Equation 1 & Equation 2 & Equation 3 & Equation 4 & Equation 5 & Equation 6 & Equation 7 \\
\hline GDP & $\begin{array}{l}0.2 * * * \\
(3.00)\end{array}$ & $\begin{array}{l}0.2 * * \\
(1.98)\end{array}$ & $\begin{array}{c}0.12 * * * \\
(2.77)\end{array}$ & $\begin{array}{c}0.1^{*} \\
(2.09)\end{array}$ & $\begin{array}{l}0.2 * * * \\
(5.05)\end{array}$ & $\begin{array}{c}0.24 * * * \\
(7.22)\end{array}$ & $\begin{array}{l}0.4 * * * \\
(3.65)\end{array}$ \\
\hline $\begin{array}{l}\text { Government capital } \\
\text { expenditure }\end{array}$ & $\begin{array}{l}0.1 * * * \\
(4.60)\end{array}$ & $\begin{array}{l}0.2^{* * * *} \\
(3.47)\end{array}$ & $\begin{array}{l}0.1 * * * \\
(3.54)\end{array}$ & $\begin{array}{c}0.02 \\
(0.88)\end{array}$ & $\begin{array}{l}0.1 * * * \\
(3.67)\end{array}$ & $\begin{array}{c}0.01 \\
(0.36)\end{array}$ & $\begin{array}{c}0.15 \text { **** } \\
(3.37)\end{array}$ \\
\hline External balance & $\begin{array}{c}1.68 \mathrm{E}-11 * * * \\
(7.81)\end{array}$ & $\begin{array}{l}1.75 \mathrm{E}- \\
11 * * * \\
(9.36)\end{array}$ & $\begin{array}{l}1.36 \mathrm{E}- \\
11 * * * \\
(5.14)\end{array}$ & $\begin{array}{l}1.97 \mathrm{E}- \\
11 * * * \\
(7.50)\end{array}$ & $\begin{array}{l}1.73 \mathrm{E}- \\
11 * * * \\
(9.68)\end{array}$ & $\begin{array}{l}2.06 \mathrm{E}- \\
11 * * * \\
(6.34)\end{array}$ & $\begin{array}{l}1.99 \mathrm{E}- \\
11 * * * \\
(7.58)\end{array}$ \\
\hline Inflation & $\begin{array}{c}-0.21 * * * \\
(-6.47)\end{array}$ & $\begin{array}{c}-0.31 * * * \\
(5.77) \\
\end{array}$ & $\begin{array}{c}-0.15 * * * \\
(-4.34) \\
\end{array}$ & $\begin{array}{c}-0.01 \\
(-0.33) \\
\end{array}$ & $\begin{array}{c}-0.21 * * * \\
(4.53) \\
\end{array}$ & $\begin{array}{c}-0.1^{*} \\
(-2.59) \\
\end{array}$ & $\begin{array}{c}-0.36 * * * \\
(-5.43)\end{array}$ \\
\hline Average governance & $\begin{array}{l}0.5 * * * \\
(5.80)\end{array}$ & & & & & & \\
\hline Political instability & & $\begin{array}{c}0.15^{* * * *} \\
(2.74)\end{array}$ & & & & & \\
\hline Corruption control & & & $\begin{array}{c}0.41 * * * \\
(11.07)\end{array}$ & & & & \\
\hline $\begin{array}{l}\text { Government } \\
\text { effectiveness }\end{array}$ & & & & $\begin{array}{c}0.57 * * * \\
(9.28)\end{array}$ & & & \\
\hline $\begin{array}{l}\text { Voice and } \\
\text { accountability }\end{array}$ & & & & & $\begin{array}{c}0.21 * * * \\
(4.65)\end{array}$ & & \\
\hline Regulatory quality & & & & & & $\begin{array}{c}0.41 * * * \\
(8.25)\end{array}$ & \\
\hline Rule of law & & & & & & & $\begin{array}{c}-0.44 * * \\
(-2.84)\end{array}$ \\
\hline Constant & $\begin{array}{c}-5.11 * * * \\
(-2.97)\end{array}$ & $\begin{array}{c}-6.50 * * * \\
(-4.37)\end{array}$ & $\begin{array}{c}-3.69 * * * \\
(-3.70)\end{array}$ & $\begin{array}{c}-2.33 * * * \\
(-3.54)\end{array}$ & $\begin{array}{c}-5.55 * * * \\
(-7.45)\end{array}$ & $\begin{array}{c}-4.84 * * * \\
(-8.79)\end{array}$ & $\begin{array}{c}-10.56 * * * \\
(-6.84)\end{array}$ \\
\hline $\begin{array}{l}\begin{array}{l}\text { Number of } \\
\text { observations }\end{array} \\
\end{array}$ & 231 & 231 & 231 & 231 & 231 & 231 & 231 \\
\hline R-squared & 0.73 & 0.72 & 0.78 & 0.87 & 0.72 & 0.82 & 0.74 \\
\hline
\end{tabular}

Source: Author's own calculations

A stable political environment will have a positive impact on the stock of infrastructure in the region. Many sub-Saharan African countries have been experiencing deteriorating physical infrastructure facilities and vandalism because of the frequent political unrest in the region. Consequently, a more stable political environment (unit increase in political instability) will result into an increase in physical infrastructure by about $0.15 \%$ (equation 2 ). The indicator for the control of corruption revealed a stronger impact on infrastructure, with an increase of about $0.41 \%$ when corruption decreases by a unit (equation 3 ). The level of corruption in the economy - especially in the public sector - will directly affect infrastructure expenditure. Corrupt practices have been a major setback for rapid infrastructure development in sub-Saharan Africa, as most allocations to this component of expenditure end up in the pockets of private individuals; and even when these funds are channelled properly, poor-quality infrastructure stock is erected.

The capacity of the government to effectively formulate and implement sound policies will also be directly reflected in its ability to provide adequate infrastructure facilities to its citizens. Therefore, a more effective government, including high-quality service delivery and minimal bureaucracy, is expected to provide better-quality infrastructure. From equation 4, a unit increase in government effectiveness will lead to an increase of about $0.57 \%$ in infrastructure, while voice and accountability - the process of selecting, monitoring and replacing those in authorities - will exact an increase of about $0.2 \%$ in infrastructure. Sound and strict regulatory control will increase infrastructure by about $0.41 \%$.

\section{CONCLUSIONS AND RECOMMENDATIONS}

The aim of this study was to empirically examine the development of physical infrastructure in 21 selected sub-Saharan African countries. The estimations performed (after controlling for other macroeconomic factors) portrayed a robust estimate of the parameters in the models. The stylised facts presented on infrastructure and 
governance revealed that an improvement in governance will have a direct and positive impact on the region's infrastructure stock. Countries with better governance ratings have also been able to provide good-quality infrastructure stock.

The results of the study confirm that the macroeconomic variables (real output, government capital expenditure, external balance and inflation) are significant determinants of physical infrastructure in sub-Saharan Africa. This corroborates the existing literature.

The distinctive feature of this study was the significant role played by governance in explaining the stock of physical infrastructure in sub-Saharan Africa. The results of the panel estimations revealed that a more stable socioeconomic and political environment, a corruption-free society, an effective public service, a sound regulatory environment and a transparent leadership structure will all boost infrastructure and, hence, create an economic environment that will attract the inflow of direct investment. This suggests that investment in governance/institutional structures themselves is a necessary first step in attaining pro-poor long-term economic growth for the region.

These results have critical policy implications if broad-based, job-inclusive economic growth is to be achieved in sub-Saharan Africa. Therefore, there is an urgent need to refocus the government's role on certain critical areas of the economy. Government institutions need to be strengthened by improving coordination within government structures, and the political environment must become more stable in order to attract higher levels of private investment. The maintenance of public order, the assurance of property rights, a sound regulatory structure, the creation of a framework that will increase the provision of public goods and services and the maintenance of infrastructure are all urgent if the set developmental objectives are to be achieved.

Moreover, infrastructure remains the greatest challenge to the continent's development (Brixiova, Mutambatsere, Ambert, and Etienne, 2011). According to estimates from Africa Infrastructure Country Diagnostic (AICD), the continent needs about a $\$ 93$ billion investment in infrastructure per annum in order to achieve its development target; only half of this amount is available. The recent emergence of public-private partnerships could help to reduce the investment deficits, but these can be achieved only if better governance structures are established in the region.

\section{AUTHOR INFORMATION}

Dr. Olusegun Ayodele Akanbi is an Associate Professor of Economics at the University of South Africa. He holds a $\mathrm{PhD}$ in Economics with specialisation in macro-econometric modelling from University of Pretoria. $\mathrm{He}$ is an academia with a private sector experience in quantitative analysis. He worked for Pan-African Investment \& Research Services (PAIRS), Johannesburg in the capacity as a Senior Economist \& Head of Research. He has also worked for the Department of Strategic Policy and Review at the International Monetary Fund (IMF) Washington D.C. focusing on debt sustainability among the low-income countries. Dr. Akanbi has led and participated in a number of major projects across South Africa. E-mail: $\underline{\text { akanboa@unisa.ac.za }}$

\section{REFERENCES}

1. Asian Development Bank (ADB). 2009. Elements of governance: understanding the conditions necessary for good governance. Manila. Available at: http://www.adb.org/governance/elements.asp

2. Bourque, P.J. 1985. The infrastructure gap. Growth and Change, Vol.16, No.1, pp.17-23.

3. Brixiova, Z., Mutambatsere, E., Ambert, C., and Etienne, D. 2011. Closing Africa's infrastructure gap: innovative financing and risks. African Development Bank: Africa Economic Brief, Vol.2, No.1.

4. Calderón, C. 2009. Infrastructure and growth in Africa. World Bank Policy Research Working Paper Series, No.4914.

5. Calderón, C., and Servén, L. 2004. The effects of infrastructure development on growth and income distribution. World Bank Policy Research Working Paper Series, No.3400.

6. De, P. 2010. Governance, institutions, and regional infrastructure in Asia. Asian Development Bank Institute Working Paper Series, No.183. 
7. Dixit, A. 2009. Governance institutions and economic activity. American Economic Review, Vol.99, No.1, pp.5-24.

8. Easterly, W. 2001. The lost decades: explaining developing countries' stagnation in spite of reform 19801998. Journal of Economic Growth, Vol.6, No.2, pp.135-157.

9. $\quad$ Enders, W. 2004. Applied econometric time series, $2^{\text {nd }}$ ed. New York: John Wiley and Sons.

10. Gulati, M., and Rao, M. 2006. Checking corruption in the electricity sector. Mimeo. Washington, D.C.: World Bank.

11. Hammami, M., Ruhashyankiko, J., and Yehoue, E.B. 2006. Determinants of public-private partnerships in infrastructure. International Monetary Fund Working Paper Series, No. 99.

12. Kandiero, T. 2009. Infrastructure investment in Africa. African Development Bank: Development Research Brief, August, No.10.

13. Kaufmann, D., Kraay, A., and Zoido-Lobaton, P. 1999. Aggregating governance indicators. World Bank Policy Research Working Paper Series, No.2195.

14. Kenny, C. 2009. Measuring corruption in infrastructure: evidence from transition and developing countries. Journal of Development Studies, Vol.45, No.3, pp.314-32.

15. Kenny, C. 2007. Infrastructure governance and corruption: where next? World Bank Policy Research Working Paper Series, No.4331.

16. Kolstad, I., and Wiig, A. 2009. Is transparency the key to reducing corruption in resource-rich countries? World Development, Vol. 37, No.3, pp.521-32.

17. Kuroda, H., Kawai, M., and Nangia, R. 2007. Infrastructure and regional cooperation, in Rethinking infrastructure for development, edited by Bourguignon, F. and Pleskovic, B. Washington, D.C: World Bank.

18. Loayza, N., Fajnzylber, P., and Calderón, C. 2005. Economic growth in Latin America and the Caribbean: stylized facts, explanations and forecasts. World Bank Latin American and Caribbean Studies. Washington, D.C.: World Bank.

19. Munnell, A. 1990. Is there a shortfall in public capital investment? Boston: Federal Reserve Bank of Boston.

20. Organisation for Economic Co-operation and Development (OECD). 2009. Infrastructure investment: links to growth and the role of public policy, in Economic policy reforms: going for growth. Paris.

21. Rodrik, D., Subramanian, A., and Trebbi, F. 2004. Institutions rule: the primacy of institutions over geography and integration in economic development. Journal of Economic Growth, Vol.9, pp.131-165.

22. Smith, L.I. 2002. A tutorial on principal components analysis. Available at: http://www.cs.otago.ac.nz/cosc453/student_tutorials/principal_components.pdf

23. World Bank. 1994. World Development Report: infrastructure for development. Washington, D.C. 


\section{APPENDIX A}

\section{Principal Components Analysis}

\begin{tabular}{|c|c|c|c|c|c|}
\hline \multicolumn{6}{|c|}{ Eigenvalues: $($ sum $=3$, average $=1)$} \\
\hline Number & Value & Difference & Proportion & $\begin{array}{l}\text { Cumulative } \\
\text { value }\end{array}$ & $\begin{array}{l}\text { Cumulative } \\
\text { proportion }\end{array}$ \\
\hline 1 & 1.475194 & 0.507926 & 0.4917 & 1.475194 & 0.4917 \\
\hline 2 & 0.967268 & 0.409730 & 0.3224 & 2.442462 & 0.8142 \\
\hline 3 & 0.557538 & --- & 0.1858 & 3.000000 & 1.0000 \\
\hline \multicolumn{6}{|c|}{ Eigenvectors (loadings): } \\
\hline Variable & PC 1 & PC 2 & PC 3 & & \\
\hline Electricity & 0.276095 & 0.953500 & -0.120873 & & \\
\hline Roads & -0.668537 & 0.280873 & 0.688599 & & \\
\hline Telecommunication & 0.690529 & -0.109311 & 0.714997 & & \\
\hline
\end{tabular}

Source: Author's own calculations

\section{APPENDIX B}

\section{List of Countries}

\begin{tabular}{|l|l|}
\hline Botswana & Angola \\
\hline South Africa & Zambia \\
\hline Togo & Ghana \\
\hline Congo & Sudan \\
\hline Ethiopia & Mozambique \\
\hline Namibia & Nigeria \\
\hline Gabon & Benin \\
\hline Cote d'Ivoire & Tanzania \\
\hline Cameroon & Senegal \\
\hline Kenya & Congo, Dem. Rep. \\
\hline Zimbabwe & \\
\hline
\end{tabular}

